Article

\title{
Effect of Chloride Ions on Electro-Coagulation to Treat Industrial Wastewater Containing $\mathrm{Cu}$ and $\mathrm{Ni}$
}

\author{
Chien-Hung Huang ${ }^{1}$, Shan-Yi Shen ${ }^{2}{ }^{\oplus}$, Chiu-Wen Chen ${ }^{3}$, Cheng-Di Dong ${ }^{3}{ }^{(0)}$, \\ Mohanraj Kumar ${ }^{2}$, Balasubramanian Dakshinamoorthy ${ }^{4}$ and Jih-Hsing Chang ${ }^{2, * \mathbb{D}}$ \\ 1 Department of Health Wellness and Marketing, Kainan University, Taoyuan 33857, Taiwan; \\ huang@mail.knu.edu.tw \\ 2 Department of Environmental Engineering and Management, Chaoyang University of Technology, \\ Taichung 41349, Taiwan; shanyi0226@gmail.com (S.-Y.S.); mohan1991mpt@gmail.com (M.K.) \\ 3 Department of Marine Environmental Engineering, National Kaohsiung University of Science and \\ Technology, Kaohsiung 81157, Taiwan; cwchen@nkust.edu.tw (C.-W.C.); cddong@nkust.edu.tw (C.-D.D.) \\ 4 Raman Research Laboratory, PG \& Research Department of Physics, Government Arts College, \\ Tiruvannamalai 606603, Tamilnadu, India; balad67@rediffmail.com \\ * Correspondence: changjh@cyut.edu.tw; Tel.: +886-4-23323000 (ext. 7485); Fax: +886-4-23742365
}

Received: 7 August 2020; Accepted: 12 September 2020; Published: 17 September 2020

\begin{abstract}
A series of experiments with different $\mathrm{NaCl}$ concentrations added to the PCB (printed circuit board) wastewater were prepared to investigate the chloride effect on the formation of aluminum floc and removal efficiency of $\mathrm{Cu}$ and $\mathrm{Ni}$. The effects of $\mathrm{pH}$, current density, and different concentration of $\mathrm{NaCl}$ were studied and the results are discussed. Results imply that chloride ions are favored to avoid the passivation of the aluminum anode in the EC (electro-coagulation) system. Chloride ions used as the electrolyte can facilitate the release of $\mathrm{Al}^{3+}$, which results in the current efficiency of over $100 \%$ in the EC system. For the PCB factory's wastewater, the EC system could remove $\mathrm{Cu}^{2+}$ and $\mathrm{Ni}^{2+}$ effectively (both $\mathrm{Cu}$ and $\mathrm{Ni}$ concentration of treated wastewater was less than $1.0 \mathrm{mg} / \mathrm{L}$ within three minutes). PCB wastewater's pH value could maintain stably about 9.0 in the EC system when the initial $\mathrm{pH}$ value was around 2.5. The estimated electricity consumption for treating PCB wastewater by the EC process was about $0.894 \mathrm{kWh}$ for each meter of cubic wastewater.
\end{abstract}

Keywords: copper; current efficiency; electro-coagulation; nickel; wastewater

\section{Introduction}

The electro-coagulation (EC) technique has received considerable attention to remove heavy metals from the industrial wastewater for decades. Several researchers expect to use the EC process to replace the traditional chemical coagulation [1-3]. The advantages of EC compared to the conventional chemical coagulation include simple operation, effective and rapid removal, extensive $\mathrm{pH}$ range, and acceptable cost [4-7]. To create the coagula, the attractive force with Van der Waals must overcome the repulsive force within the double layer of the suspending particles. By adding the coagulant, agents can reduce the electrostatic repulsion and further decrease the distance of the electrical double-layer [8,9]. The EC approach employs the same coagulation mechanism as the above. In an EC system, the electro-dissolution of sacrificial anodes forms complexed species with hydroxide ions, which act as coagulant agents to separate pollutants from the wastewater. The extreme reactions of EC technology include (1) metallic ions generated by the sacrificial anode ( $\mathrm{Al}$ or Fe is commonly used) in the reaction tank, (2) hydroxide ions generated by cathode to form floc, (3) the occurrence of coagulation precipitation (e.g., $\mathrm{Al}(\mathrm{OH})_{3}$ ) and (4) the metallic and organic pollutants which could be separated from the aqueous phase by such coagula $[10,11]$. Furthermore, the hydrogen bubble generated in the 
cathode can be used to achieve the effect of agitation or flotation. Hence, the coagulation purpose can be achieved without adding chemicals or mechanical agitation during the EC process. The above reaction rates are fast (usually takes only a few minutes). To consider all kinds of organic and inorganic pollutants, the EC method can be used to remove them effectively [1,2,12-15]. However, the operation cost of the EC method might be relatively higher due to its electricity consumed; therefore, to be competitive with the traditional chemical coagulation method, more researches need to be explored to obtain proper and effective operation parameters.

To control all kinds of chemical reactions smoothly during electrochemical methods to process waste material, the electrical potential or current control is one of the essential operating parameters. Generally, the electrical potential that the EC method needs to surmount to generate current among electrode plates includes balance potential, concentration over-potential, activation over-potential, and ohm over-potential [2,16]. To avoid the concentration, activity, and electrical polarization is beneficial to reduce the voltage, save energy, and let the reaction happen smoothly. Accordingly, the addition of electrolytes in wastewater can increase conductivity (i.e., a decrease of the high polarization) and reduce the voltage to achieve energy-saving. The commonly used electrolyte includes $\mathrm{KCl}, \mathrm{NaCl}$, and $\mathrm{NaNO}_{3}$. The chloride ions will have pitting corrosion on the metallic anode plate, which can avoid the generation of the passivation layer on the anode plate surface and the subsequent resistance polarization [17-21]. Based on previous studies under the operation condition of a fixed voltage, the EC system can maintain at a current stable state by adding nitrate ions, the $\mathrm{Al}$ ions dissolved from the anode, and $\mathrm{OH}$ - generated on the cathode. However, due to the over-rise of $\mathrm{pH}$ value (i.e., $\mathrm{pH}$ over 9.0), $\mathrm{Al}(\mathrm{OH})_{4}^{-}$thus becomes the main species and floc cannot be formed.

In contrast, by adding chlorine salt in the EC system, the solution $\mathrm{pH}$ shows a trend of first ascending and later descending and then maintains at a steady range of 9-10. As a result, $\mathrm{Al}(\mathrm{OH})_{3}$ floc can be formed, and heavy metals can be removed quickly and effectively [19]. Accordingly, the chloride ions have been chosen as the electrolyte in the EC system to treat the printed circuit board (PCB) wastewater in this study.

The printed circuit board (PCB) is the essential component in most electrical and electronic devices, whose primary function is to support the electrical units and link the electrical circuits [22]. The PCB fabricating processes include edge trimming, copper cladding, protective film, drilling pad, overlaying, and scraping plate, which will produce acidic/alkali wastewater with a high concentration of inorganic/organic pollutants [23-25]. Water consumption can be as high as $1.5 \mathrm{~m}^{3}$ per $\mathrm{m}^{2}$ of the board processed [26]. In Taiwan, more than 100,000 tons of PCB are generated annually [27]. Such complicated sewage is one of the most common factory wastewaters. Moreover, these metallic ions exist in a stable state of coordination complexes with benzotriazole, 2-aminothiazole, and other organic ligands, which significantly influences the treatment effectiveness [28]. The discharge of untreated PCB wastewater will bring a massive threat to the environment and result in a waste of valuable resources $[29,30]$. The discharge standard of $\mathrm{Cu}$ and $\mathrm{Ni}$ is $3 \mathrm{mg} / \mathrm{L}$ and $1 \mathrm{mg} / \mathrm{L}$, respectively, in Taiwan, and it is hard to meet such criteria dealing with PCB wastewater. Consequently, it is very urgent to develop a cost-effectiveness and sustainable remediating technique for PCB wastewater.

In this study, a series of experiments with different concentrations of $\mathrm{NaCl}$ added to the wastewater (different initial $\mathrm{pH}$ values of sewage as well) were prepared to investigate the chloride effect on the formation of aluminum floc. Under different current densities, the relationship among the release amount of aluminum ions, voltage change, and the consumed electricity of the EC system was established. Moreover, wastewater containing $\mathrm{Cu}$ and Ni from individual PCB plants was used for the EC process to observe the removal efficiency of heavy metals. Through this study, the practical operational parameters of the EC process can be obtained for further application. 


\section{Materials and Methods}

\subsection{Experimental and Equipment}

The EC experimental setup is shown in Figure 1. A polyvinylchloride (PVC) reaction tank (total volume of reaction tank of $250 \mathrm{~cm}^{3}$ ) was set up, with a metallic aluminum plate used as an anode. In the present study a graphite plate was used as a cathode with an area of $82 \mathrm{~cm}^{2} . \mathrm{NaCl}$ added in the solution for this study was purchased from Riedel-de Haen, USA, with a purity of $99.6 \%$. Sulfuric acid (Merck, $>95 \%$ ) and $\mathrm{NaOH}$ (Sigma-Aldrich, $>97 \%$ ) were used for acidic or basic adjustment of the solution. During the operation, the solution within the reaction tank was internally circulated with a quantitative motor (with flow rate adjusted to $250 \mathrm{~cm}^{3} / \mathrm{min}$ ) to ensure that the solution was well mixed. A programmable power supply (DC) was employed to provide the current to EC reactions. The DC power supply is manufactured by MOTECH INDUSTRIES INC with a model number of PPS1002F/CE/MT (0 to $18 \mathrm{~V}, 0$ to $4 \mathrm{~A}$ ), which can read the voltage values.

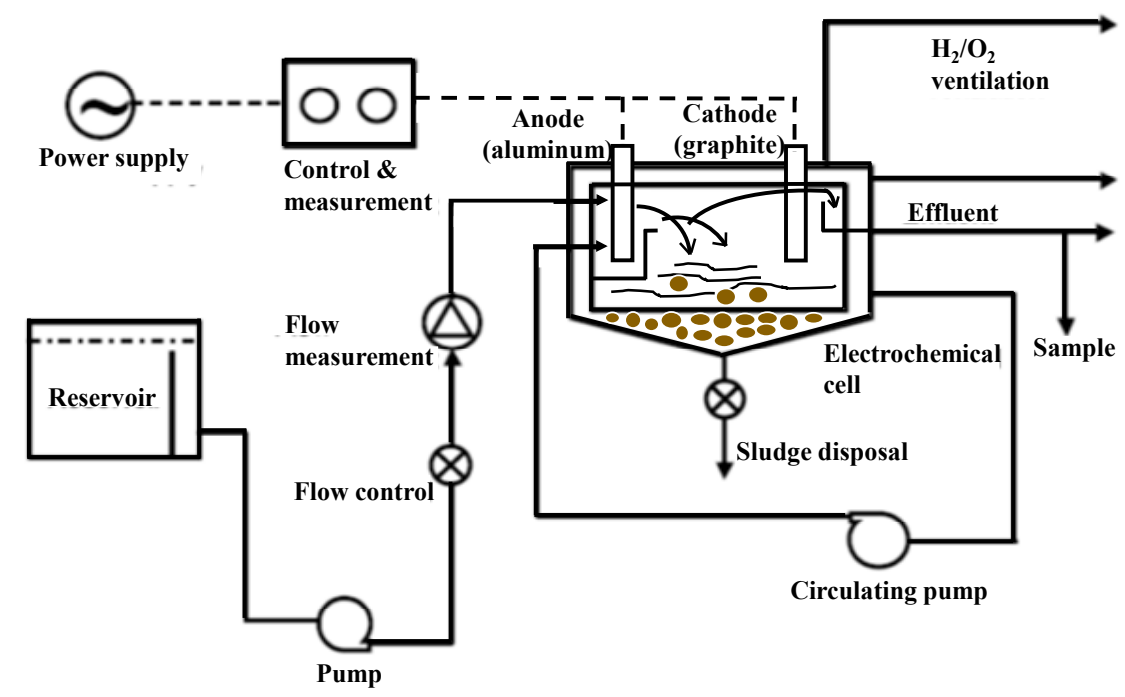

Figure 1. Schematics of electro-coagulation (EC) experimental setup [20].

\subsection{Experimental Method}

A constant current was applied at $0.5 \mathrm{~A}, 1.0 \mathrm{~A}, 1.5 \mathrm{~A}$, and $2.0 \mathrm{~A}$ (i.e., the current densities were $60.98 \mathrm{~A} / \mathrm{m}^{2}, 121.95 \mathrm{~A} / \mathrm{m}^{2}, 182.93 \mathrm{~A} / \mathrm{m}^{2}$, and $243.90 \mathrm{~A} / \mathrm{m}^{2}$, respectively). The high current densities in subsequent figures were represented individually by integral values of $60 \mathrm{~A} / \mathrm{m}^{2}, 120 \mathrm{~A} / \mathrm{m}^{2}, 180 \mathrm{~A} / \mathrm{m}^{2}$, and $240 \mathrm{~A} / \mathrm{m}^{2}$. To investigate the effect on voltage and consumed electricity by chlorine ions in the wastewater, different concentrations of $\mathrm{NaCl}$ were controlled in the EC system, namely, $1.00 \mathrm{~g} / \mathrm{L}, 1.75 \mathrm{~g} / \mathrm{L}$, and $2.5 \mathrm{~g} / \mathrm{L}$, then operated for $10 \mathrm{~min}$. An appropriate amount of $\mathrm{NaCl}$ was selected according to the previous experimental results, then EC was operated for $20 \mathrm{~min}$. During the EC process, the dissolved amount of $\mathrm{Al}$ ion was recorded to establish the relationship between $\mathrm{Al}$ release magnitude and current density. Meanwhile, the corrosion phenomenon by chlorine ions during the EC process could be understood by the weight loss of aluminum anode. Since the $\mathrm{pH}$ of the solution mainly controls the chemical coagulation, the $\mathrm{pH}$ of the solution was monitored ( $\mathrm{pH}$ meter, Suntex, SP-701) during the EC process to evaluate the floc formation.

In order to understand the practical feasibility of the $\mathrm{EC}$ technique for wastewater containing heavy metals, $\mathrm{Cu}$ and $\mathrm{Ni}$ from a real plant (PCB process) were used for the experiment. Within the operation time, the voltage and $\mathrm{pH}$ value of wastewater was determined. Also, the conductivity was measured (Conductivity meter, Suntex, SC-170). Following a 20-min EC treatment, the formed flocs precipitated for $30 \mathrm{~min}$. The upper supernatant was sampled to determine the concentration of $\mathrm{Cu}$ and Ni by inductively coupled plasma atomic emission spectrometer (Thermo, IRIS Intrepid II XSP). 
All water samples were triple repeat analyzed, and the average value was taken to ensure the water sample stability.

\section{Results and Discussion}

\subsection{Mechanism of EC}

When metallic $\mathrm{Al}$ is used as the anode and graphite as the cathode in an EC system, the initial reactions are generated as the following Equations (1)-(4):

(a) Oxidation reactions at the anode:

$$
\begin{gathered}
\mathrm{Al}_{(\mathrm{s})} \rightarrow \mathrm{Al}^{3+}+3 \mathrm{e}^{-} \\
2 \mathrm{H}_{2} \mathrm{O} \rightarrow \mathrm{O}_{2(\mathrm{~g})}+4 \mathrm{H}^{+}+4 \mathrm{e}^{-}
\end{gathered}
$$

(b) Reduction reaction at the cathode:

$$
2 \mathrm{H}_{2} \mathrm{O}+2 \mathrm{e}^{-} \rightarrow \mathrm{H}_{2(\mathrm{~g})}+2 \mathrm{OH}^{-}
$$

(c) $\mathrm{Al}^{3+}$ ions generated at the anode will form $\mathrm{Al}(\mathrm{OH})_{3}$ floc in the solution with $\mathrm{OH}^{-}$generated at the cathode:

$$
\mathrm{Al}^{3+}+3 \mathrm{OH}^{-} \rightarrow \mathrm{Al}(\mathrm{OH})_{3(\mathrm{~s})}
$$

Theoretically, $\mathrm{Al}^{3+}$ ions will have different electrolytic forms such as $\mathrm{Al}(\mathrm{OH})^{2+}, \mathrm{Al}(\mathrm{OH})_{2}^{+}, \mathrm{Al}(\mathrm{OH})_{4}^{-}$, etc., along with the $\mathrm{pH}$ change of the solution. Al polymer-form hydrolytic products, such as $\mathrm{Al}_{2}(\mathrm{OH})_{2}^{4+}$, $\mathrm{Al}_{3}(\mathrm{OH})_{4}^{5+}, \mathrm{Al}_{6}(\mathrm{OH})_{15}^{3+}, \mathrm{Al}_{7}(\mathrm{OH})_{17}^{4+}, \mathrm{Al}_{8}(\mathrm{OH})_{20}^{4+}, \mathrm{Al}_{13} \mathrm{O}_{4}(\mathrm{OH})_{24}^{5+}$ and $\mathrm{Al}_{13}(\mathrm{OH})_{34}^{5+}$, will be generated as well [31,32]. The $\mathrm{Al}(\mathrm{OH})_{3}$ floc will adsorb contaminants in the wastewater, which can remove contaminants effectively after precipitation. Accordingly, the optimum operating parameters of the EC system should be ensured to be applicable. For the actual condition of this study, the $\mathrm{Al}^{3+}$ ions can be generated at the anode under the aluminum anode was used in the electro-coagulation operation, which can form a hydroxide of $\mathrm{Al}(\mathrm{OH})_{3}$ and easily remove the heavy metals from the wastewater. The pollutants in wastewater can be removed through adsorption, co-precipitation, and other reaction mechanisms [16]. Figure 2 illustrates a schematic diagram of the EC technique mechanism for the removal of $\mathrm{Cu}(\mathrm{II})$ and $\mathrm{Ni}(\mathrm{II})$ from industrial wastewater.

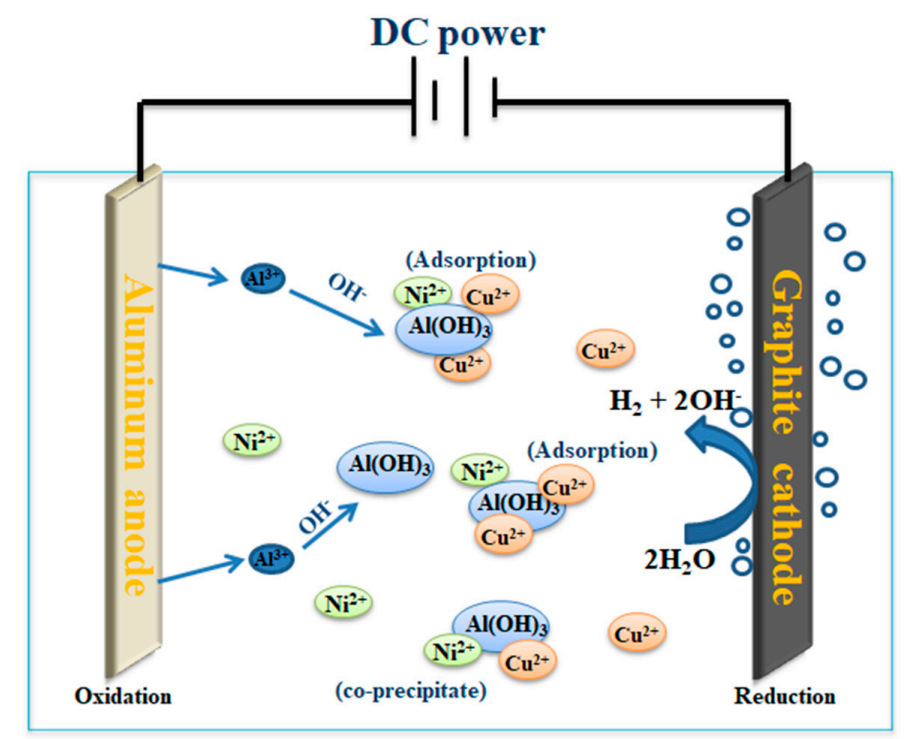

Figure 2. Schematic diagram of the EC technique mechanism for the removal of $\mathrm{Cu}$ (II) and $\mathrm{Ni}$ (II) from industrial wastewater. 


\subsection{The Effect of $\mathrm{NaCl}$ on Voltage and Consumed Electricity}

Figure 3 shows the consumed power (watts) as a function of current density $\left(\mathrm{A} \mathrm{m}^{-2}\right)$ under different dosage concentrations of $\mathrm{NaCl}$. It can be seen that the current density increased with significant growth of the consumed electricity. According to Ohm's law, the voltage is proportional to current. The electrical potential (voltage) is mainly ohm over-potential of solution (that is, the voltage needed to surmount solution resistance) $\eta_{I R}$ or called IR-drop (5):

$$
\eta_{\mathrm{IR}}=\frac{\mathrm{Id}}{\mathrm{AK}}
$$

where I is current, $\mathrm{d}$ is the spacing between the electrode plate, $\mathrm{A}$ is the surface area of the electrode plate, and $\mathrm{K}$ is conductivity. Since I, $\mathrm{d}$ and A are all constant values, $\eta_{\mathrm{IR}}$ is reversely proportional to conductivity $\mathrm{K}$. The $\mathrm{NaCl}$ dosage increases conductivity ( $\mathrm{K}$ value is more substantial); the voltage needed for the reaction is thus lower.

Since the consumed electricity is related to power P (Unit: W), 1 degree of electricity is $1 \mathrm{kWh}$ (kilowatt-hour):

$$
\mathrm{P}=\mathrm{VI}
$$

where $\mathrm{V}$ is the voltage, and $\mathrm{V}$ (voltage) is proportional to $\mathrm{P}$ (power).

According to the above equation, the increased voltage enhances the consumed electricity in the EC system. To consider the influence of chloride ions, it could be noticed that higher $\mathrm{NaCl}$ dosage obtained lower consumed power under the same current density. This means the higher electrolyte concentration (high $\mathrm{NaCl}$ dosage) created higher electrical conductivity, which resulted in lower voltage under the same current density.

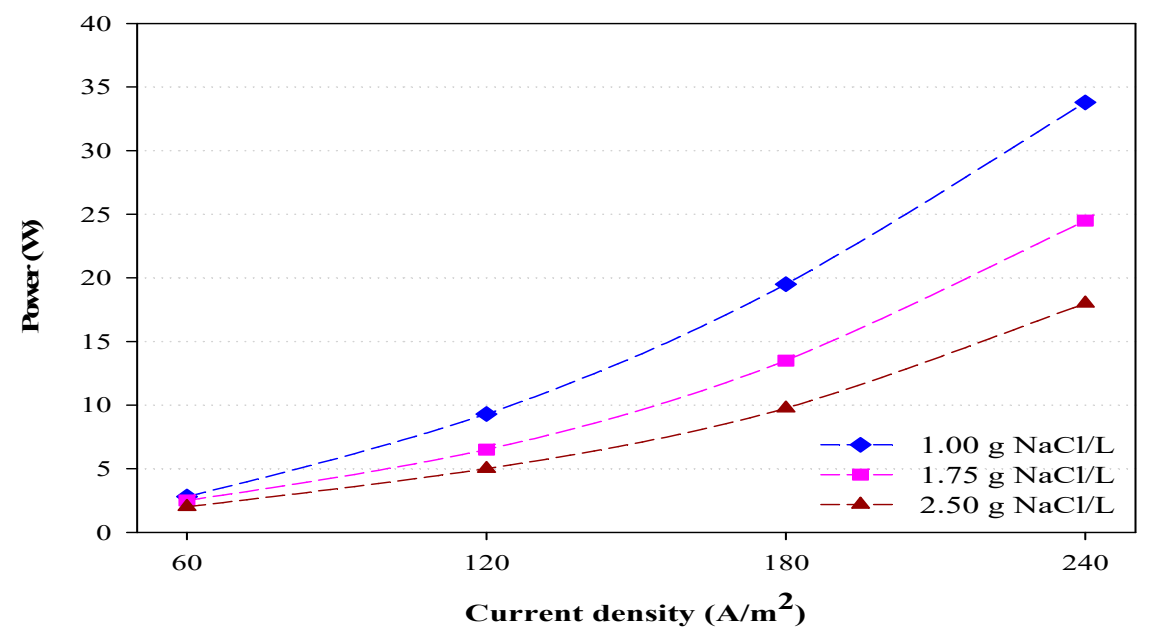

Figure 3. Consumed electricity (watts) as a function of current density $\left(\mathrm{A} / \mathrm{m}^{2}\right)$ under different $\mathrm{NaCl}$ concentrations.

\subsection{Aluminum Dissolved Amount and Current Efficiency}

Figure 4 showed the relationship between the $\mathrm{Al}$ dissolution amount and current density under different $\mathrm{NaCl}$ concentrations. From the figure, it could be seen that $\mathrm{Al}$ dissolution was proportional to the current density and is independent of $\mathrm{NaCl}$ concentration. Based on equation (1), the $\mathrm{Al}$ anode will release aluminum ions due to oxidation reaction (i.e., lose electrons). Consequently, more electrons involved in the EC system cause more free $\mathrm{Al}$ ions. To consider the effect of chloride ions, $\mathrm{Cl}^{-}$ions could avoid the formation of the oxide layer on the anode surface. When the oxide layer is formed at the anode, the chloride ions could react with the oxide layer and decompose such a high-resistance layer. Under the same current density, high $\mathrm{NaCl}$ concentration only decreased the voltage rather than increasing the $\mathrm{Al}$ dissolution amount. It can be attributed that the chloride ions prevent the interface of 
the aluminum anode from impurities that hinders the oxidation of aluminum dissolution. A particular concentration of chloride could maintain the clean surface of the anode. Namely, the chloride effect becomes insignificant when the level of chloride ions is over the proper parameter.

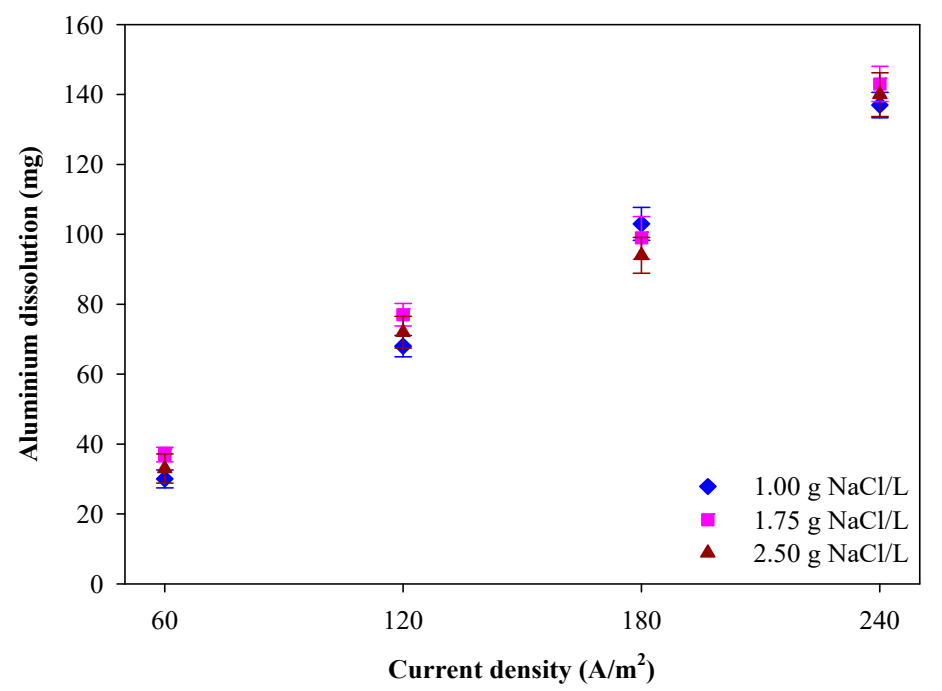

Figure 4. Relationship between $\mathrm{Al}$ dissolution amount and current density under different $\mathrm{NaCl}$ concentrations.

Figure 5 shows the relationship between $\mathrm{Al}$ dissolution amount and operation time under different $\mathrm{NaCl}$ concentrations. It could be observed that the $\mathrm{Al}$ dissolution amount was proportional to operation time since the number of electrons (current multiplied time) controlled the extent of electrochemical reaction, which illustrated the dissolution amount of $\mathrm{Al}$ associated with operational time. Meanwhile, the higher current density led to the linear equation (i.e., the dissolution rate of $\mathrm{Al}$ is quicker), which meant more flocs could be obtained in the shorter operational time. This phenomenon implies that the formation of flocs in the EC system was associated directly with the number of electrons from the electrochemical reaction. The $\mathrm{Al}$ dissolution being faster caused more electricity to be consumed.

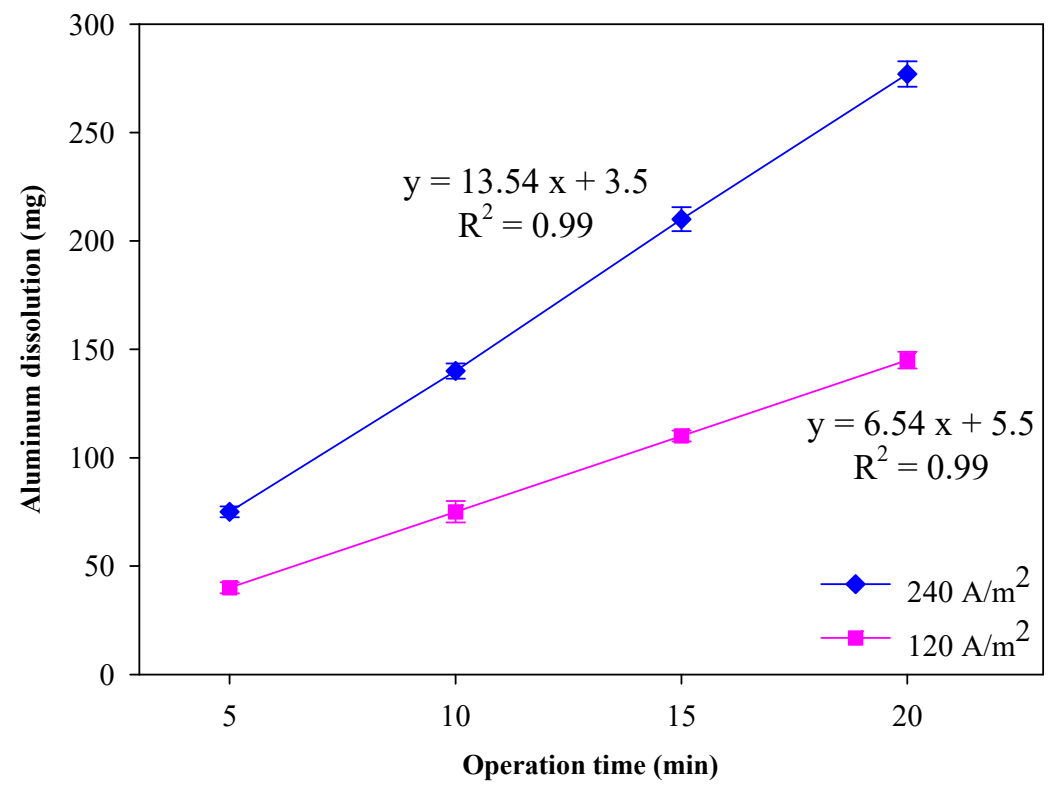

Figure 5. Relationship between $\mathrm{Al}$ dissolution amount and operation time under different $\mathrm{NaCl}$ concentrations. 
Table 1 lists the $\mathrm{Al}$ dissolved amount and current efficiency under different operation currents and $\mathrm{NaCl}$ concentrations. To consider the current efficiency of the EC system, it can be computed as the following (7) and (8):

$$
\begin{gathered}
\Phi=\frac{\mathrm{m}_{\mathrm{Al}(\mathrm{R})}}{\mathrm{m}_{\mathrm{Al}(\mathrm{T})}} \times 100 \% \\
\mathrm{~m}_{\mathrm{Al}(\mathrm{T})}=\frac{\mathrm{ItM}}{\mathrm{nF}}
\end{gathered}
$$

where $\mathrm{m}_{\mathrm{Al}(\mathrm{R})}$ and $\mathrm{m}_{\mathrm{Al}(\mathrm{T})}$ are the actual and theoretical weight loss of $\mathrm{Al}$ anode, respectively, and the term $\Phi$ is the current efficiency. The value of $\mathrm{m}_{\mathrm{Al}(\mathrm{T})}$ is calculated from Faraday law, $\mathrm{I}$ is current, $\mathrm{t}$ is reaction time, $\mathrm{M}$ is atomic weight, $\mathrm{n}$ is valence number, and $\mathrm{F}$ is the Faraday constant of 96,500 coulombs. From the data in Table 1, it could be seen that current efficiencies were all greater than $100 \%$. Theoretically, the current efficiency of the electrochemical reaction is less than $1.0(<100 \%)$ because not all electrons are involved in the Al dissociation. However, many EC research results showed that the current efficiency was more significant than $1.0(>100 \%)$. If both cathode and anode are used with Al material, current efficiency can even be over 1.5. Some researchers called this phenomenon "super faradaic efficiencies" [33]. This specific situation could be attributed to the "pitting corrosion reaction" of chloride ions on the anode [34]. Such a reaction might be attributed to the following reactions (9)-(11).

$$
\begin{aligned}
2 \mathrm{Cl}^{-} & \rightarrow \mathrm{Cl}_{2}+2 \mathrm{e}^{-} \\
\mathrm{Cl}_{2}+\mathrm{H}_{2} \mathrm{O} & \rightarrow \mathrm{HOCl}+\mathrm{H}^{+}+\mathrm{Cl}^{-} \\
\mathrm{HOCl} & \rightarrow \mathrm{H}^{+}+\mathrm{OCl}^{-}
\end{aligned}
$$

The chloride ions can transform to $\mathrm{HOCl}$ that oxide the aluminum atom to produce $\mathrm{Al}^{3+}$ ions. $\mathrm{The} \mathrm{HOCl}$ is a more potent oxidant than chlorine under standard conditions.

Table 1. The Al dissolved amount and current efficiency under different operation currents and $\mathrm{NaCl}$ concentrations.

\begin{tabular}{ccccc}
\hline Current (A) & $\mathbf{N a C l}\left(\mathbf{g ~ L}^{-\mathbf{1}}\right)$ & $\mathbf{V}_{\text {avg }}(\mathbf{V})$ & $\mathbf{m}_{\mathbf{A l}(\mathbf{R})}(\mathbf{m g})$ & $\boldsymbol{\Phi} \mathbf{( \% )}$ \\
\hline \multirow{3}{*}{$0.5\left(60 \mathrm{~A} / \mathrm{m}^{2}\right)$} & 1.00 & 5.24 & 28 & 100 \\
& 1.75 & 3.82 & 35 & 125 \\
& 2.50 & 3.05 & 33 & 118 \\
\hline \multirow{2}{*}{$1.0\left(120 \mathrm{~A} / \mathrm{m}^{2}\right)$} & 1.00 & 9.27 & 66 & 118 \\
& 1.75 & 6.15 & 75 & 134 \\
& 2.50 & 4.89 & 71 & 127 \\
\hline & 1.00 & 13.10 & 102 & 122 \\
& 1.75 & 9.06 & 98 & 117 \\
& 2.50 & 6.73 & 93 & 111 \\
\hline & 1.00 & 16.70 & 138 & 123 \\
& 1.75 & 12.03 & 144 & 129 \\
\hline
\end{tabular}

\subsection{The $p H$ Variation of Wastewater during EC Operation}

Figure 6 showed the $\mathrm{pH}$ variation with operational time under a current density of $120 \mathrm{~A} / \mathrm{m}^{2}$ and $1.75 \mathrm{~g} / \mathrm{L} \mathrm{NaCl}$. The flocs formed effectively in the EC system should be maintained at $\mathrm{pH}$ ranging from 6.0 to 9.0, according to equation 4. In this study, the PCB wastewater usually has a low $\mathrm{pH}$ value. From Figure 6, it could be noticed that the initial $\mathrm{pH}$ value of the sewer was 2.0, 2.5, 3.0, and 7.0, respectively. After a 20-min operation, most $\mathrm{pH}$ values of wastewater, except the initial $\mathrm{pH}$ of 2.0, could be increased up to around 9.0. The main factor that causes the rise of $\mathrm{pH}$ based on equation (3) is the contribution of $\mathrm{OH}^{-}$generated from the reduction reaction of the cathode. As the wastewater was 
filled with too much acid, the EC system would fail due to the low final $\mathrm{pH}$ of sewage in the EC system (i.e., no flocs will be formed).

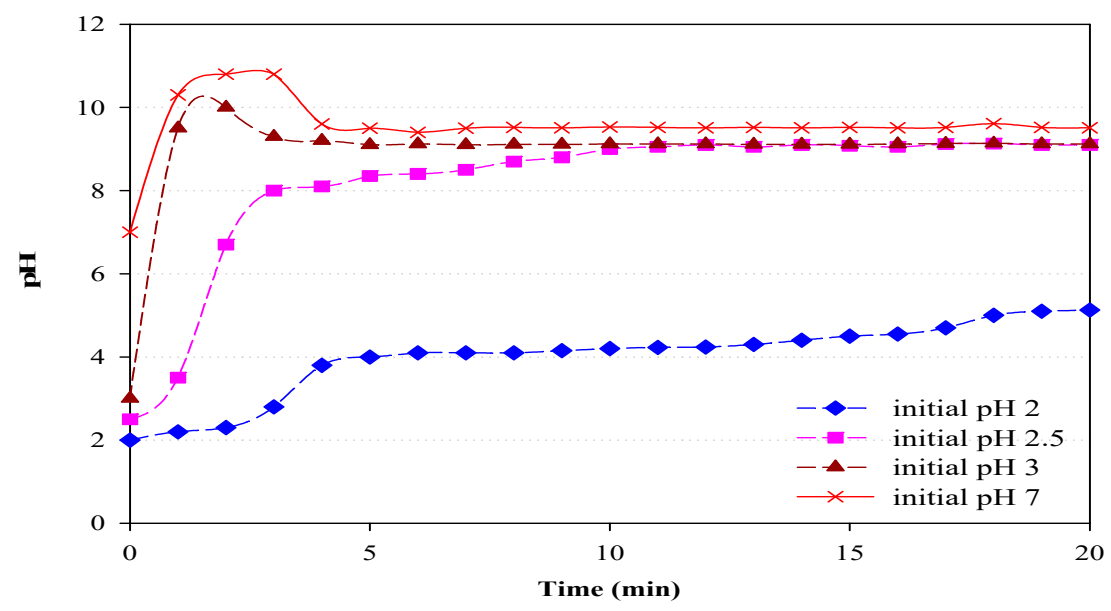

Figure 6. $\mathrm{pH}$ variation with operational time under a current density of $120 \mathrm{~A} / \mathrm{m}^{2}$ and $1.75 \mathrm{~g} / \mathrm{L} \mathrm{NaCl}$.

\subsection{The Removal Efficiency of $\mathrm{Cu}$ and Ni Wastewater by EC Process}

Figure 7 shows the removal efficiency of $\mathrm{Cu}$ and $\mathrm{Ni}$ wastewater after EC treatment under the current of $1.0 \mathrm{~A}$ and $1.75 \mathrm{~g} / \mathrm{L} \mathrm{NaCl}$. The initial concentration of $\mathrm{Cu}$ and $\mathrm{Ni}$ in the PCB wastewater was about $10 \mathrm{mg} / \mathrm{L}$ and the initial $\mathrm{pH}$ was 3.0. After 10-min EC treatment, the final $\mathrm{pH}$ was 7.76; the average voltage was $6.27 \mathrm{~V}$, anode $\mathrm{Al}$ weight loss was $70 \mathrm{mg}$, and current efficiency reached $117 \%$. According to Figure 7, it could be observed that the heavy metal concentrations of $\mathrm{Cu}$ and $\mathrm{Ni}$ were both reduced to below $1.0 \mathrm{mg} / \mathrm{L}$ after a 3-min operation; both heavy metals could not be detected after 8-min treatment. The result shows that $\mathrm{Cu}$ and $\mathrm{Ni}$ in the PCB wastewater could be entirely removed under such an EC system and meet regulatory standards. Finally, the determined results were compared with the previous report which is shown in Table 2. Based on the results described in Table 2, it can be noted that the EC has tremendous potential to transform emerging technology and traditional approaches to wastewater management. Here, the $\mathrm{EC}$ is sufficient to recycle water for industrial or domestic recycling because this $\mathrm{EC}$ mechanism completely eliminates $\mathrm{Cu}$ and $\mathrm{Ni}$ compared to other reports. Moreover, based on data regarding the electricity consumption, the cost of electricity consumed for this processing could be estimated at around $0.894 \mathrm{kWh}$ each meter cubic of wastewater.

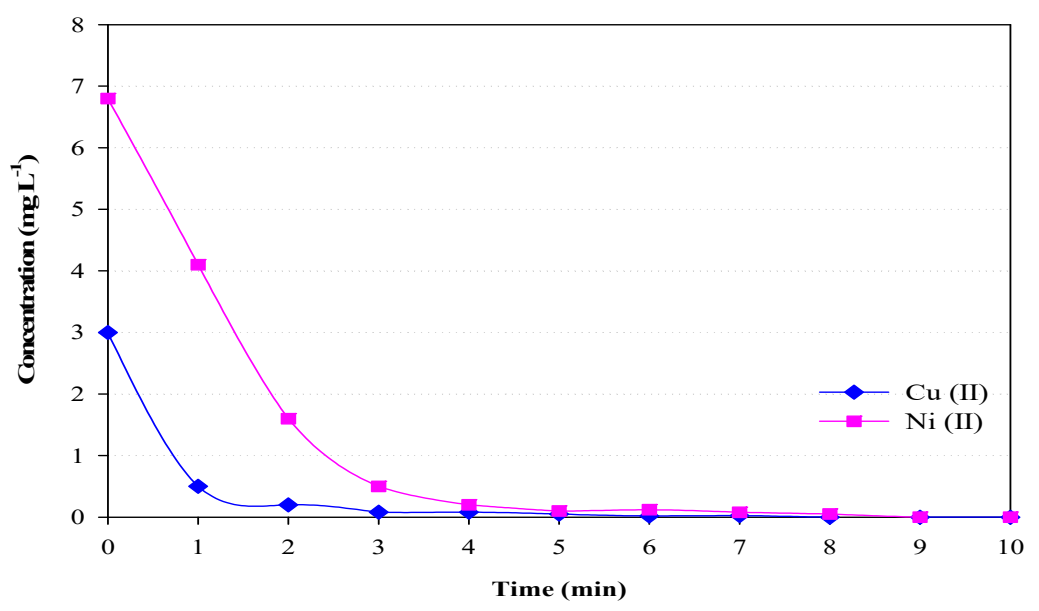

Figure 7. The removal efficiency of $\mathrm{Cu}$ and $\mathrm{Ni}$ wastewater after EC treatment under the current of 1.0 A and $1.75 \mathrm{~g} / \mathrm{L} \mathrm{NaCl}$. 
Table 2. The comparison table for the EC treatment with previous reports.

\begin{tabular}{|c|c|c|c|c|c|c|}
\hline $\begin{array}{c}\text { Type of } \\
\text { Wastewater }\end{array}$ & $\begin{array}{l}\text { Electrode } \\
\text { Combination }\end{array}$ & $\begin{array}{l}\text { Optimum } \\
\text { Initial pH }\end{array}$ & EC Time & $\begin{array}{l}\text { Optimum } \\
\text { Current } \\
\text { Density or } \\
\text { Current }\end{array}$ & $\begin{array}{c}\text { \% Pollutant } \\
\text { Removal }\end{array}$ & Reference \\
\hline $\begin{array}{c}\text { Municipal } \\
\text { wastewater }\end{array}$ & $\mathrm{Al}-\mathrm{Al}$ & $7.4-8.5$ & $20 \mathrm{~min}$ & $4 \mathrm{~mA} / \mathrm{cm}^{2}$ & $\begin{array}{c}90 \% \text { for } \\
\text { COD, } 94.56 \% \\
\text { for turbidity } \\
\text { and } 49.78 \% \\
\text { for TDS }\end{array}$ & $\begin{array}{c}\text { Nawarkar, } \\
\text { et.al., 2019 } \\
\text { [35] }\end{array}$ \\
\hline $\begin{array}{c}\text { Textile } \\
\text { wastewater }\end{array}$ & $\mathrm{Fe}-\mathrm{Al}$ & 8 & $\begin{array}{c}80 \text { min-COD, } \\
60 \text { min-Color } \\
\text { removal }\end{array}$ & $2 \mathrm{~mA} / \mathrm{cm}^{2}$ & $\begin{array}{l}90 \% \text { COD, } \\
99 \% \text { for } \\
\text { Color } \\
\text { removal }\end{array}$ & $\begin{array}{c}\text { Verma, } 2017 \\
{[36]}\end{array}$ \\
\hline $\begin{array}{l}\text { Metalworking } \\
\text { fluid } \\
\text { wastewater }\end{array}$ & $\mathrm{Al}-\mathrm{Al}, \mathrm{Fe}-\mathrm{Fe}$ & $\begin{array}{l}6.5 \text { for } \mathrm{Al}, 7.5 \\
\text { for } \mathrm{Fe}\end{array}$ & $25 \mathrm{~min}$ & $80 \mathrm{~A} / \mathrm{m}^{2}$ & $\begin{array}{c}94 \% \text { COD } \\
(\mathrm{Al}), 90 \% \\
\text { COD } \\
(\mathrm{Fe}) .83 \% \\
\text { TOC }(\mathrm{Al}), \\
80 \% \mathrm{TOC} \\
(\mathrm{Fe})\end{array}$ & $\begin{array}{c}\text { Demirbas, } \\
\text { et.al., (2016) } \\
{[37]}\end{array}$ \\
\hline $\begin{array}{l}\text { Olive oil mill } \\
\text { wastewater }\end{array}$ & $\mathrm{Ti}-\mathrm{Fe}$ & 5.2 & $60 \mathrm{~min}$ & $\begin{array}{c}39.06,78.1 \\
\text { and } 117.18 \\
\mathrm{~A} / \mathrm{m}^{2}\end{array}$ & $\begin{array}{c}\text { COD and } \\
\text { phenolic } \\
\text { compounds } \\
\text { were } 99.89 \% \text {, } \\
96.14 \% \text { and } \\
89.97 \%\end{array}$ & $\begin{array}{l}\text { Yazdanbakhsh, } \\
\text { et.al., (2013) } \\
{[38]}\end{array}$ \\
\hline $\begin{array}{c}\text { Printed } \\
\text { circuit board } \\
(\text { PCB }) \\
\text { industrial } \\
\text { Wastewater }\end{array}$ & Al-Graphite & 3.0 & $3-8 \mathrm{~min}$ & $1.0 \mathrm{~A}$ & $\begin{array}{c}3 \mathrm{~min}< \\
(\mathrm{Cu} \& \mathrm{Ni}) \\
1.0 \mathrm{mg} / \mathrm{L} \\
100 \% \\
\text { removal (8 } \\
\text { min) }\end{array}$ & Present work \\
\hline
\end{tabular}

\section{Conclusions}

According to experimental results, several conclusions can be drawn:

(1) Chloride ions are favored to avoid the passivation of the aluminum anode in the EC system.

(2) Chloride ions used as the electrolyte can facilitate the release of $\mathrm{Al}^{3+}$, which results in the current efficiency of over $100 \%$ in the EC system.

(3) For the wastewater of the PCB (printed circuit board) factory, the EC system could remove $\mathrm{Cu}^{2+}$ and $\mathrm{Ni}^{2+}$ effectively (both $\mathrm{Cu}$ and $\mathrm{Ni}$ concentration of treated wastewater were less than $1.0 \mathrm{mg} / \mathrm{L}$ within three minutes).

(4) The $\mathrm{pH}$ value of PCB wastewater could maintain stably about 9.0 in the EC system when the initial $\mathrm{pH}$ value was around 2.5 .

(5) The estimated electricity consumption for treating PCB wastewater by the EC process was pertaining to $0.894 \mathrm{kWh}$ for each meter of cubic wastewater.

Author Contributions: Conceptualization and methodology-J.-H.C., C.-D.D. and C.-H.H.; formal analysis, investigation and data curation-C.-H.H.; validation, C.-W.C.; writing-original draft preparation-C.-H.H and S.-Y.S.; writing-review and editing-M.K., B.D. and S.-Y.S.; supervision-J.-H.C. and C.-D.D. All authors have read and agreed to the published version of the manuscript.

Funding: This research received no external funding.

Conflicts of Interest: The authors declare no conflict of interest. 


\section{References}

1. Emamjomeh, M.M.; Sivakumar, M. Review of pollutant removed by electrocoagulation and electrocoagulation/flotation processes. J. Environ. Manag. 2009, 90, 1663-1679. [CrossRef] [PubMed]

2. Chen, G. Electrochemical technology in wastewater treatment. Sep. Purif. Technol. 2004, 38, 11-41. [CrossRef]

3. Amarine, M.; Lekhlif, B.; Sinan, M.; Rharras, A.E.; Echaabi, J. Treatment of nitrate-rich groundwater using electrocoagulation with aluminum anodes. Groundw. Sustain. Dev. 2020, 11, 100371. [CrossRef]

4. Brillas, E.; Martínez-Huitle, C.A. Decontamination of wastewaters containing synthetic organic dyes by electrochemical methods, An updated review. Appl. Catal. B Environ. 2015, 166-167, 603-643. [CrossRef]

5. Tahreen, A.; Jami, M.S.; Ali, F. Role of electrocoagulation in wastewater treatment: A developmental review. J. Water Process Eng. 2020, 37, 101440. [CrossRef]

6. Tsopbou Ngueagni, P.; Djoufac Woumfo, E.; Senthil Kumar, P.; Siéwé, M.; Vieillard, J.; Brun, N.; Fotsing Nkuigue, P. Adsorption of $\mathrm{Cu}(\mathrm{II})$ ions by modified horn core: Effect of temperature on adsorbent preparation and extended application in river water. J. Mol. Liq. 2020, 298, 112023. [CrossRef]

7. Meunier, N.; Drogui, P.; Montané, C.; Hausler, R.; Mercier, G.; Blais, J.F. Comparison between electrocoagulation and chemical precipitation for metals removal from acidic soil leachate. J. Hazard. Mater. 2006, 137, 581-590. [CrossRef]

8. Missana, T.; Adell, A. On the applicability of DLVO theory to the prediction of clay colloids stability. J. Colloid Interface Sci. 2000, 230, 150-156. [CrossRef] [PubMed]

9. Garcia-Segura, S.; Eiband, M.M.S.G.; de Melo, J.V.; Martínez-Huitle, C.A. Electrocoagulation and advanced electrocoagulation processes: A general review about the fundamentals, emerging applications and its association with other technologies. J. Electroanal. Chem. 2017, 801, 267-299. [CrossRef]

10. Pernitsky, D.J.; Edzwald, J.K. Selection of alum and polyaluminum coagulants: Principles and applications. J. Water Supply Res. Technol. 2006, 55, 121-141. [CrossRef]

11. Jiang, J.Q. The role of coagulation in water treatment. Curr. Opin. Chem. Eng. 2015, 8, 36-44. [CrossRef]

12. Yang, C.L.; Kravets, G. Removal of cadmium in leachate from waste alumina beads using electrochemical technology. Chem. Eng. Commun. 2002, 189, 827-848. [CrossRef]

13. Yang, C.L. Electrochemical coagulation for oily water demulsification. Sep. Purif. Technol. 2007, 54, 388-395. [CrossRef]

14. Merzouk, B.; Gourich, B.; Sekki, A.; Madani, K.; Chibane, M. Removal turbidity and separation of heavy metals using electrocoagulation-electroflotation technique A case study. J. Hazard. Mater. 2009, 164, 215-222. [CrossRef]

15. Murugananthan, M.; Raju, G.B.; Prabhakar, S. Removal of sulfide, sulfate and sulfite ions by electro coagulation. J. Hazard. Mater. 2004, 109, 37-44. [CrossRef]

16. Mollah, M.Y.A.; Morkovsky, P.; Gomes, J.A.G.; Kesmez, M.; Parga, J.; Cocke, D.L. Fundamentals, present and future perspectives of electrocoagulation. J. Hazard. Mater. 2004, 114, 199-210. [CrossRef] [PubMed]

17. Hu, C.Y.; Lo, S.L.; Kuan, W.H. Effects of co-existing anions on Fluoride removal in electrocoagulation(EC) process using aluminum electrodes. Water Res. 2003, 37, 4513-4523. [CrossRef]

18. Adhoum, N.; Monser, L.; Bellakhal, N.; Belgaied, J.E. Treatment of electroplating wastewater containing $\mathrm{Cu}^{2+}, \mathrm{Zn}^{2+}$ and $\mathrm{Cr}(\mathrm{VI})$ by electrocoagulation. J. Hazard. Mater. 2004, 112, 207-213. [CrossRef]

19. Huang, C.H.; Chen, L.; Yang, C.L. Effect of anions on electrochemical coagulation for cadmium removal. Sep. Purif. Technol. 2009, 65, 137-146. [CrossRef]

20. Chang, J.H.; Chang Chien, S.W.; Dong, C.D.; Chen, C.W.; Huang, C.H.; Shen, S.Y. The coinage refractory wastewater treated by electrocatalytic-membrane process (ECMP) integrated with chemical-or electro-coagulation techniques. Process Saf. Environ. Prot. 2019, 125, 182-188. [CrossRef]

21. Trompette, J.L.; Vergnes, H. On the crucial influence of some supporting electrolytes during electrocoagulation in the presence of aluminum electrodes. J. Hazard. Mater. 2009, 163, 1282-1288. [CrossRef]

22. de Souza, W.B.; Abreu, C.S.; Rodrigues, G.D.; Mageste, A.B.; de Lemos, L.R. Selective separation of Cu, $\mathrm{Ni}$ and $\mathrm{Ag}$ from printed circuit board waste using an environmentally safe technique. J. Environ. Manag. 2018, 226, 76-82. [CrossRef]

23. Hossain, N.; Bhuiyan, M.A.; Pramanik, B.K.; Nizamuddin, S.; Griffin, G. Waste materials for wastewater treatment and waste adsorbents for biofuel and cement supplement applications: A critical review. J. Clean. Prod. 2020, 255, 120261. [CrossRef] 
24. Gwak, G.; Kim, D.I.; Hong, S. New industrial application of forward osmosis (FO): Precious metal recovery from printed circuit board (PCB) plant wastewater. J. Membr. Sci. 2018, 552, 234-242. [CrossRef]

25. LaDou, J. Printed circuit board industry. Int. J. Hyg. Environ. Health 2006, 209, 211-219. [CrossRef] [PubMed]

26. Goosey, M. Water use in the printed circuit board manufacturing process and approaches for reducing consumption. Circuit World 2005, 31, 22-23. [CrossRef]

27. Mymrin, V.; Guidolin, M.A.; Klitzke, W.; Alekseev, K.; Guidolin, R.H.; Avanci, M.A.; Pawlowsky, U.; Winter, E., Jr.; Catai, R.E. Environmentally clean ceramics from printed circuit board sludge, red mud of bauxite treatment and steel slag. J. Clean. Prod. 2017, 164, 831-839. [CrossRef]

28. Min, X.; Luo, X.; Deng, F.; Shao, P.; Wu, X.; Dionysiou, D.D. Combination of multi-oxidation process and electrolysis for pretreatment of PCB industry wastewater and recovery of highly-purified copper. Chem. Eng. J. 2018, 354, 228-236. [CrossRef]

29. Zhou, L.; Xu, Z. Response to waste electrical and electronic equipments in china: Legislation, recycling system, and advanced integrated process. Environ. Sci. Technol. 2012, 46, 4713-4724. [CrossRef]

30. Yang, J.G.; Wu, Y.T.; Li, J. Recovery of ultrafine copper particles from metal components of waste printed circuit boards. Hydrometallurgy 2012, 121-124, 1-6. [CrossRef]

31. Mouedhen, G.; Feki, M.; Wery, M.D.P.; Ayedi, H.F. Behavior of aluminum electrodes in electrocoagulation process. J. Hazard. Mater. 2008, 150, 124-135. [CrossRef] [PubMed]

32. Yousuf A Mollah, M.; Schennach, R.; Parga, J.R.; Cocke, D.L. Electrocoagulation(EC)—Science and applications. J. Hazard. Mater. 2001, 84, 29-41. [CrossRef]

33. Ivonne, L.H.; Carlos, B.D.; Gabriela, R.M.; Bilyeu, B.; Fernando, U.N. Influence of the anodic material on electrocoaulation performance. Chem. Eng. J. 2009, 148, 97-105.

34. Cañizares, P.; Carmona, M.; Lobato, J.; Martinez, F.; Rodrigo, M.A. Electrodissolution of Aluminum Electrodes in Electrocoagulation Process. Ind. Eng. Chem. Res. 2005, 44, 4178-4185. [CrossRef]

35. Nawarkara, C.J.; Salkar, V.D. Solar powered Electrocoagulation system for municipal wastewater treatment. Fuel 2019, 237, 222-226. [CrossRef]

36. Verma, A.K. Treatment of textile wastewaters by electrocoagulation employing Fe-Al composite electrode. J. Water Process Eng. 2017, 20, 168-172. [CrossRef]

37. Demirbas, E.; Kobya, M. Operating cost and treatment of metalworking fluid wastewater by chemical coagulation and electrocoagulation processes. Process Saf. Environ. Prot. 2017, 105, 79-90. [CrossRef]

38. Yazdanbakhsh, A.R.; Massoudinejad, M.R.; Arman, K.; Aghayani, E. Investigating the Potential of Electro-Coagulation-Flotation (ECF) Process for Pollutants Removal from Olive Oil Mill Wastewater. J. Appl. Environ. Biol. Sci. 2013, 3, 22-28.

(C) 2020 by the authors. Licensee MDPI, Basel, Switzerland. This article is an open access article distributed under the terms and conditions of the Creative Commons Attribution (CC BY) license (http://creativecommons.org/licenses/by/4.0/). 